ROCZNIKI TEOLOGICZNE

Tom LXVII, zeszyt 6 - 2020

DOI: http://dx.doi.org/10.18290/rt.20676-3

KS. BOGDAN BIELA

\title{
KSIĄDZ FRANCISZEK BLACHNICKI - PREKURSOR TEOLOGII KERYGMATYCZNEJ W POLSCE
}

\author{
FATHER FRANCISZEK BLACHNICKI \\ - A FORERUNNER OF KERYGMATIC THEOLOGY IN POLAND
}

\begin{abstract}
A b stra ct. Pope Francis said, "Theology after Veritatis Gaudium is a kerygmatic theology, a theology of discernment, of mercy and of welcoming, in dialogue with society, cultures and religions for the construction of the peaceful coexistence of individuals and peoples" (21.06.2019). In this context, a forerunner of kerygmatic theology in Poland, Father Franciszek Blachnicki (1921-1987), seems to be a person to focus on. As a theoretician, he came up with foundations of fundamental catechesis, in which he emphasised the fact that contemporary forms of catechumenate do not fit the requirements of the contemporary times. Blachnicki knew that the central pastoral issue of the Church is loss of the environment of living faith and love that may welcome new generations of Christians. The existing system of catechesis for children and youth is understood as a school subject to be taught purely on an intellectual level is not able to meet the tasks of catechumenate, since it is not an educational system that introduces Christian life in the community of the Church. In view of the above, Blachnicki was convinced that an additional catechumenate for the baptised was necessary - both for adults, youth and children. This complementary catechumenate should use the guidelines offered by the post-conciliar teaching of the Church, especially the one offered in the document on Christian initiation of adults. As the result of this, in the sixties of the last century, Father Blachnicki used the scheme of "Oasis" retreat to found the Living Church Movement, later known as the Light-Life Movement. Within the framework of deuterocatechumenal formation, he showed a specific way of implementing postulates, resulting directly from the achievements of kerygmatic theology and offered a "catechumenate-oriented" concept of pastoral care able to renew the contemporary parish that is a community of communities.
\end{abstract}

Key words: kerygmatic theology; catechumenate; Light-Life Movement; parish.

Ks. dr hab. Bogdan BiElA, prof. UŚ w Katowicach - Instytut Nauk Teologicznych Wydziału Teologicznego Uniwersytetu Śląskiego w Katowicach; adres do korespondencji: ul. Markowej 15B/8, 41-709 Ruda Śl. 9; e-mail: bogdan.biela@us.edu.pl; ORCID: http://orcid.org/0000-0001-9105-7536

Rev. Bogdan BIEla, Prof. of UŚ - Theological Sciences Institute of the University of Silesia in Katowice; address for correspondence: ul. Markowej 15B/8, 41-709 Ruda Śl. 9; e-mail: bogdan.biela@us.edu. pl; ORCID: http://orcid.org/0000-0001-9105-7536 
Zabierając głos 21 czerwca 2019 r. podczas kongresu na temat „Teologia po «Veritatis gaudium» w kontekście śródziemnomorskim”, zorganizowanym przez Papieski Wydział Teologiczny Południowych Włoch w Neapolu, papież Franciszek stwierdził, iż „Teologia po Veritatis Gaudium jest teologią kerygmatyczną, teologią rozeznania, miłosierdzia i przyjęcia, w dialogu ze społeczeństwem, kulturami i religiami, w celu budowania pokojowego współistnienia jednostek i narodów"1. Szeroko omawiajając temat dialogu, akceptacji i miłosierdzia, papież nie rozwija tematu teologii kerygmatycznej. Kerygmat czy ewangelizację traktuje raczej hasłowo i horyzontalnie. Podobnie zresztą jak w Konstytucji apostolskiej o uniwersytetach i wydziałach kościelnych Veritatis gaudium (08.12.2017), gdy podając ,podstawowe kryteria odnowienia i odrodzenia wkładu studiów kościelnych", zwraca uwagę przede wszystkim na społeczny wymiar ewangelizacji (por. nr 4).

O teologii kerygmatycznej możemy już mówić od dobrych kilkudziesięciu lat² Upowszechnienie pojęcia „kerygmat” we współczesnej teologii oraz nadanie mu

\footnotetext{
${ }^{1}$ http://www.vatican.va/content/francesco/en/speeches/2019/june/documents/papa-francesco 20190621_teologia-napoli.html. [dostęp: 25.11.2019]. Por. https://stacja7.pl/bez-kategorii/franciszek-zaapelowal-w-neapolu-o-rozwijanie-teologii-dialogu-i-akceptacji/. [dostęp: 25.11.2019]. Papież w wykładzie nawiązuje do Konstytucji apostolskiej „Veritatis gaudium - o uniwersytetach i wydziałach kościelnych" z 8.12.2017.

${ }^{2}$ Praktyka „katechezy kerygmatycznej” jako głoszenia wtajemniczającego w wiarę została zapomniana wraz z zanikiem katechumenatu w VIII i IX wieku. W jej miejsce pojawiła się praktyka uczenia dzieci „katechizmu” w domach. Pisał o tym św. Tomasz z Akwinu w swej Sumie teologicznej (STh III q. 71, a. 1). Z czasem, zwłaszcza w wyniku rozwoju sztuki drukarskiej w XV wieku, pojawiły się podręczniki, spisane zbiory prawd wiary w formie książkowej. Mimo akcentowania przez reformację w XVI wieku wagi głoszonego przekazu o zbawieniu, w gronie protestantów i katolików mnożyły się podręczniki zwane katechizmami (np. Katechizm Rzymski o charakterze kontrreformacyjnym czy Maty katechizm Marcina Lutra). Naturalistyczne i moralizatorskie ujęcie katechezy z czasów oświecenia spowodowało powstanie na przełomie XVIII i XIX wieku w gronie pastoralistów obszarów języka niemieckiego związanych ze szkołą tybińską (Johann Michael Sailer, Bernhard Overberg, Johann Baptist Hirscher) idei przywrócenia katechezie jej pierwotnego, biblijnego ujęcia. W konsekwencji rozwijała się katecheza kerygmatyczna, której podstawę stanowiło Objawienie Boże. W stosunkowo krótkim czasie nurt ten został osłabiony przez odnawiającą się scholastykę, ale ożywający przed I wojną światową ruch biblijny i liturgiczny pozwolił na powrót idei katechezy kerygmatycznej z początku XIX wieku. Teologia kerygmatyczna zyskała ożywienie w 1892 r. wraz z publikacją dzieła niemieckiego teologa Martina Kählera (Der sogenannte historische Jesus und der geschichtliche, biblische Christus, Münick, 1969), w którym autor skonfrontował historyczny relatywizm z apostolskim nauczaniem: „Prawdziwy Chrystus to Chrystus proklamowany, a proklamowany Chrystus to Chrystus wiary”. Po I wojnie światowej w Niemczech i Szwajcarii rozwijała się teologia dialektyczna, nurt teologii protestanckiej, w łonie którego krytyce podlegał historyzm i psychologizm teologii liberalnej. Kolejnymi dwoma istotnymi impulsami były: encyklika Divino afflante Spiritu papieża Piusa XII, która otwierała pole do rozwoju egzegezy i katechezy, oraz publikacja w 1936 r. książki Josefa Andreasa Jungmanna Die Frohbotschaft und unsere Glaubensverkündigung (Ratyzbona, 1986) w której autor postulował postawienie treści wyżej niż metody w katechezie. W $1938 \mathrm{r}$. Karl Barth - teolog protestancki - wydał
} 
rangi przekraczającej pierwotne biblijne znaczenie zawdzięczamy zarówno teologom z kręgów protestanckich, jak i katolickich z pierwszej połowy XX wieku. Zwrócono wtedy uwagę, że chrześcijaństwo przestało być przeżywane jako Dobra Nowina ogarniająca całe życie, a stało się raczej sumą zwyczajów i nakazów odczuwanych jako ciężar oraz dogmatów, w które trzeba wierzyć. Jako przyczynę tego stanu rzeczy Josef Andreas Jungmann wskazał rozdział między teologią spekulatywną a pastoralną, mianowicie, że teologia spekulatywna w zbyt małym stopniu pozostaje na usługach aktualnego przepowiadania adresowanego do współczesnego człowieka. Dlatego postulował taki sposób uprawiania teologii, który mógłby bardziej służyć kerygmatowi ${ }^{3}$. W efekcie narodził się ruch kerygmatyczny i teologia kerygmatyczna, obok spekulatywnej, która jest ściśle ukierunkowana na służbę przepowiadaniu. Postulaty odnowy kerygmatycznej znalazły później swoje odzwierciedlenie w nauczaniu Soboru Watykańskiego II, w rozwijających się dynamicznie po soborze ruchach odnowy Kościoła i współcześnie w wezwaniu do nowej ewangelizacji ${ }^{4}$. W związku z powyższym warto przypomnieć najważniejsze osiągnięcia teologii kerygmatycznej w kontekście twórczości i działalności jednego z prekursorów teologii kerygmatycznej i nowej ewangelizacji w Polsce, ks. Franciszka Blachnickiego.

\section{TEORETYK TEOLOGII KERYGMATYCZNEJ}

W dniach 6-8 maja 2003 r. zorganizowano w Katolickim Uniwersytecie Lubelskim II Międzynarodowe Forum Teologów Europy Środkowo-Wschodniej pod wymownym tytułem „Więksi i mniejsi prorocy Europy Środkowo-Wschodniej

niewielką książkę pt. Ewangelia i kształcenie, w której dowodził, iż źródła pedagogiki chrześcijańskiej nie mogą stanowić teorie pedagogiczne, ale przekaz biblijny. W sposób typowy dla tradycji protestanckiej Barth radykalnie rozdzielił religię i wiarę. Po II wojnie światowej uznanie zdobywała nowa koncepcja edukacji religijnej zwana „nauczaniem ewangelickim” (lub „,instruktarzem ewangelickim”), wpisującym się w nurt tradycji kerygmatycznej. W latach 50 . XX wieku niemiecka szkoła teologów protestanckich rozwijała się w kierunku teorii kształcenia opartej na hermeneutyce egzystencjalnej. Należący do znaczących reprezentantów tego nurtu Rudolf Bultmann, jeden z najbardziej wpływowych teologów ewangelickich XX wieku, był twórcą idei egzystencjalnego rozumienia kerygmatu chrześcijańskiego. Wraz z Barthem byli filarami protestanckiej teologii kerygmatycznej XX wieku. Zob. https://pl.wikipedia.org/wiki/Kerygmat [dostęp: 19.11.2019].

${ }^{3}$ Chodzi - krótko mówiąc - o przepowiadanie wydarzenia zbawczego dokonanego przez Jezusa Chrystusa. To wydarzenie staje się dzięki mocy Ducha Świętego obecne, angażuje egzystencjalnie słuchacza i pomaga mu opowiedzieć się za Chrystusem.

${ }^{4}$ Tomasz JAKLEwicz, „Kerygmat”, w Leksykon teologii pastoralnej, red. Ryszard Kamiński, Wiesław Przygoda i Marek Fiałkowski (Lublin: TN KUL, 2006), 371-4. 
XX wieku"5. Wśród postaci, które zostały zaprezentowane podczas tego sympozjum, znalazła się również osoba ks. F. Blachnickiego, którego zaliczono do grona „proroków większych” tej części Europy. W solidnej monografii biskupa Adama Wodarczyka, opisującej jego życie i działalność, ks. Blachnicki został wręcz nazwany „Prorokiem żywego Kościoła”.

Blachnicki już u progu swojej posługi kapłańskiej zdawał sobie sprawę, że odziedziczony model życia chrześcijańskiego, model „Kościoła ludowego”, cechujący się środowiskowym uwarunkowaniem chrześcijaństwa, jest modelem bez osobowej decyzji wiary, bez momentu decyzji nawrócenia. Model ten tworzy społeczność religijną zrzeszającą faktycznych pogan, którzy nie przekroczyli jeszcze progu religii naturalnej, ćwierć- i półchrześcijan, katechumenów, wtórnych analfabetów religijnych, pobożnych i gorliwych, de facto sekciarzy itp. - solidarnie przy tym deklarujących swoją przynależność do Kościoła z różnych względów społecznych i tradycyjnych ${ }^{7}$.

Skoro nie wychowujemy ochrzczonych do dojrzałego przeżywania swej wiary, to nie możemy się dziwić, że ich sposób życia nie jest chrześcijański. A chrześcijaństwo to właśnie sposób życia, to nowe życie. W związku z powyższym autor Katechetyki fundamentalnej (Lublin 1970) był przekonany, że dzisiejsze formy katechumenatu nie odpowiadają wymaganiom czasów współczesnych. „Zakładamy, że katechumenat istnieje, bo istnieje system nauczania religii, szkolny lub parafialny. Właśnie to założenie trzeba podważyć" - przekonywał założyciel oaz. Katechizacja jest wciąż obciążona grzechem intelektualizmu, katechumenat zaś to dużo więcej niż przekaz wiedzy religijnej - to wdrażanie do życia słowem Bożym, do modlitwy, życia sakramentalnego, ciągłego nawracania się, świadectwa i służby we wspólnocie.

Zarówno głoszenie słowa Bożego, jak i sprawowanie liturgii musi dokonywać się w łonie wspólnoty. Tę wspólnotę tworzą sami katechumeni, ale prowadzeni przez ochrzczonych chrześcijan, którzy uczą ich życia we wspólnocie. Nowy człowiek, wezwany przez słowo Boże i ukształtowany przez sakramenty, może się rozwijać faktycznie tylko w ramach wspólnoty chrześcijańskiej. Dopiero w tej koinonii, w komunii z braćmi może praktykować miłość w wymiarze krzyża. Inaczej miłość będzie czystą abstrakcją [...]. Jeżeli rozerwie się ten kontekst między słowem, sakramentem, wspólnotą, to wszystko się rozlatuje, jest fikcją. Cały problem leży w tym, że bardzo rzadko udaje się nam zebrać te wszystkie elementy razem ${ }^{8}$.

\footnotetext{
${ }^{5}$ Więksi i mniejsi prorocy Europy Środkowo-Wschodniej XX wieku, red. Karol Klauza, Stanisław Celestyn Napiórkowski i Kazimierz Pek (Lublin: Wyd. KUL, 2003).

${ }^{6}$ Adam WodarczyK, Prorok żywego Kościoła. Ks. Franciszek Blachnicki (1921-1987) -życie i działalność (Katowice: Wyd. Emmanuel, 2008).

${ }^{7}$ Franciszek BlachNicKI, „Analiza, diagnoza, terapia”, Tygodnik Powszechny 27, nr 10(1973): 1-2.

${ }^{8}$ Franciszek Blachnicki, Sympatycy czy chrześcijanie? Katechumenat na dzisiejsza godzinę, red. Dorota Franków (Krościenko: Wyd. Światło-Życie, 2002), 19-21.
} 
Blachnicki dobitnie zwracał uwagę na grzech intelektualizmu tkwiący w wadliwej koncepcji nauczania wiary, którą przyjęliśmy w XIX wieku pod wpływem epoki oświecenia, jej racjonalizmu, potem neoscholastyki i świeckiej dydaktyki. Zgodnie z wymogami teologii kerygmatycznej - mówił - wiary nie można „nauczyć”, tak jak można nauczyć geografii i matematyki. Wiarę można przekazać, jeżeli będzie się ją głosiło jako słowo Boże, które o tyle może być zasymilowane, o ile stanie się „słowem życia”, o ile będzie równocześnie podejmowany wysiłek uczynienia go zasadą i normą życia i postępowania. W przeciwnym razie przekaże się tylko czysto werbalną wiedzę religijną, która bardzo szybko pójdzie w zapomnienie. Student, który słucha wykładu z tygodnia na tydzień, robiąc notatki, streszczając je potem i wkuwając na pamięć, z trudem zdaje egzamin i wnet zapomni to wszystko, z czym się nie będzie spotykał na co dzień w życiu9. Dlatego, aby ukazać należycie problem przepowiadania, a szczególnie katechezy we współczesnym Kościele, nie można się ograniczać do zagadnień natury duszpastersko-organizacyjnej, programowej czy metodyczno-dydaktycznej. Wszystkie te zagadnienia, wprawdzie same w sobie są bardzo ważne, nie dotykają jednak najistotniejszego problemu, jakim jest kryzys samej koncepcji tradycyjnej katechezy jako aktualnej formy katechumenatu Kościoła. A zadaniem katechetyki jako nauki o kościelnym katechumenacie jest właśnie wypracowanie i wskazanie formy katechumenatu najodpowiedniejszej na daną godzinę dziejów Kościoła. Blachnickiemu nie chodziło o to, by likwidować katechizację, lecz by zmienić proporcje. Katechizacja nie wystarcza, czego najlepiej dowodzi fakt, że choć jest ona obecnie najlepiej zorganizowana, to zarazem nigdy nie było tylu jej „absolwentów” opuszczających wspólnotę Kościoła.

Katecheza, która nie prowadzi do Kościoła, prowadzi do niewiary. Co to znaczy? - pytał Blachnicki. Katecheza ma prowadzić do Kościoła, ale Kościoła w znaczeniu wspólnoty, a nie jakiejś abstrakcji. Katecheza ma prowadzić w życie wspólnoty kościelnej, czyli ma spełniać rolę dawniejszego katechumenatu, który wdrażał w życie wspólnoty. A jeżeli tej wspólnoty nie ma, to do czego ma wprowadzać katecheza? W naszych parafiach najczęściej nie ma wspólnoty. Nasze tradycyjne parafie to raczej agencje usług religijnych ${ }^{10}$.

W związku z powyższym Blachnicki był przekonany, że trzeba odnowić katechumenat rodzinny i katechumenat dorosłych, które były podstawowe w starożytnym Kościele. Nie można przesadnie skupiać się w pracy duszpasterskiej tylko na dzieciach i młodzieży. Dlatego według twórcy oaz trzeba wprowadzić uzupełniający katechumenat dla osób już ochrzczonych - zarówno dorosłych, jak i dzieci, i młodzieży

\footnotetext{
${ }^{9}$ Blachnicki, Analiza, diagnoza, terapia, 2.

${ }^{10}$ Blachnicki, Sympatycy czy chrześcijanie?, 34.
} 
- wykorzystując wskazówki posoborowego nauczania Kościoła, zwłaszcza zawarte w dokumencie o inicjacji chrześcijańskiej dorosłych ${ }^{11}$.

Przywrócenie instytucji katechumenatu jest już - według Blachnickiego - faktem dokonanym na płaszczyźnie prawodawstwa liturgicznego Kościoła. W ramach posoborowej odnowy liturgii została wydana - jako część przyszłego Rytuału Rzymskiego - księga zatytułowana Ordo Initiationis Christianae Adultorum. Konsekwencje pastoralne tej nowej księgi liturgicznej są tak wielkie i dalekosiężne, że z pewnością dużo jeszcze upłynie czasu, zanim zostaną zrozumiane i zrealizowane. W każdym razie już dziś można powiedzieć, iż pod tym względem zajmuje ona jedno z czołowych miejsc wśród wydanych po Soborze nowych ksiąg liturgicznych. [...] Z pastoralnego punktu widzenia najważniejsze w całym tym dokumencie jest faktyczne i praktyczne uznanie zasady, która doprowadziła Kościół pierwszych wieków do stworzenia instytucji katechumenatu. Zasadę tę sformułował Tertulian w sposób klasyczny w słowach: Fiunt, non nascuntur christistiani (zob. Apologeticum, 18, 4). Z żelazną konsekwencją trzymał się Kościół w tych czasach zasady, iż każdy, kto chce przystąpić do gminy (wspólnoty) Chrystusa, musi przebyć dłuższą drogę wtajemniczenia, wrastając stopniowo w świat wiary. Nikt bowiem nie rodzi się chrześcijaninem ${ }^{12}$.

Ta zasada powinna stać się motywem przewodnim stałej formacji, ponownego katechumenatu ludzi ochrzczonych. Największym bowiem problemem współczesnego chrześcijaństwa w Polsce i na całym świecie jest to, że większość wiernych nigdy nie przeżyła owego fundamentalnego wydarzenia, jakim jest odrodzenie z Boga, które by uczyniło z nich prawdziwych chrześcijan. Duszpasterz ma ich doprowadzić do takiego doświadczenia, a nie tylko opowiadać o nieskończonej miłości Bożej ${ }^{13}$. Gdyby się udało to zrealizować - mówił Blachnicki - byłaby rewolucja. Wynikiem byłaby odnowa Kościoła.

Byłby zatem Sługa Boży rewolucjonistą? - pytał w przedmowie do książki Sympatycy czy chrześcijanie Zbigniew Nosowski. Wielu może to szokować. Trzeba jednak pamiętać, że rewolucja, jaką on postuluje, polegałaby - jak to w Kościele - na powrocie do zagubionej pierwotnej tradycji. Tą tradycją jest katechumenat, a „rewolucyjne” rozważania księdza Blachnickiego to wielkie wołanie o nowe formy duszpasterstwa wykorzystujące doświadczenia starożytnego katechumenatu ${ }^{14}$.

Autor podręcznika do teologii pastoralnej (t. 1-2, Lublin 1970-1971), porównując Kościół do żywego organizmu, miał świadomość, że żyje on wtedy, gdy realizuje swoje podstawowe funkcje, które wyrażają greckie słowa: martyria, leiturgia, diakonia.

${ }^{11}$ Dokument Kongregacji Kultu Bożego, Ordo initiationis christianae adultorum, został promulgowany 6 I 1972 r. Polski przekład Obrzędów chrześcijańskiego wtajemniczenia dorostych zatwierdziła Konferencja Episkopatu Polski 12 XII 1985 r.

${ }^{12}$ Blachnicki, Sympatycy czy chrześcijanie?, 95-7.

${ }^{13}$ Tamże, 97.

${ }^{14}$ Tamże, 5. 
Martyria, czyli świadectwo - to głoszenie słowa Bożego i słuchanie tego Słowa, przyjmowanie go wiarą i wyznawanie. To jest funkcja życiowa Kościoła. Jeśli nie ma przepowiadania i wyznawania wiary, jeśli nie ma świadectwa, to Kościół jest martwy. Druga funkcja - to sprawowanie liturgii, uczestnictwo w sakramentach. I wreszcie diakonia - wzajemne służenie sobie poprzez charyzmaty, które ktoś posiada dla budowania wspólnoty. Jeżeli w Kościele jest tylko jeden pasterz, który wszystko robi, i bierne owieczki, które są tylko odbiorcami, Kościół nie wzrasta. Musi zaistnieć diakonia, czyli wszyscy muszą służyć, rozpoznać swoje zadanie. Wtedy dopiero powstaje całość. Gdy w ten sposób patrzy się na Kościół, to dochodzi się do wniosku, że funkcją życiową Kościoła, bez której on nie może żyć, rozwijać się, jest katechumenat. To znaczy, że Kościół musi posiadać jakąś instytucję, jakiś sposób, jakąś metodę, żeby wprowadzać nowe pokolenia, żeby z tych urodzonych w rodzinach chrześcijańskich zrobić prawdziwych chrześcijan, tzn. żywych, zaangażowanych, odpowiedzialnych. To nie dokonuje się automatycznie. To jest funkcja Kościoła, o której Kościół musi stale myśleć, o którą musi się troszczyć15.

F. Blachnicki miał świadomość, że centralnym problemem pastoralnym Kościoła jest utrata przez Kościół środowiska chrześcijańskiego w sensie wspólnoty żywej wiary i miłości, środowiska, które mogłoby przyjmować w siebie młode pokolenie chrześcijan. Proces religijnej, chrześcijańskiej socjalizacji został dotknięty poważnym kryzysem. Istniejący system katechizacji dzieci i młodzieży, pojętej na sposób szkolny, intelektualistyczny, jako nauczanie religii, nie potrafi w tej sytuacji spełnić zadań katechumenatu, ponieważ nie jest systemem wychowawczym, który wdraża do życia chrześcijańskiego we wspólnocie Kościoła ${ }^{16}$. W efekcie ks. Blachnicki w latach sześćdziesiątych XX wieku na bazie rekolekcji oazowych stworzył Ruch Żywego Kościoła, nazwany później Ruchem Światło-Życie (RŚŻ), w którym ukazał konkretną drogę realizacji postulatów wynikających bezpośrednio ze zdobyczy teologii kerygmatycznej.

\section{PRAKTYK TEOLOGII KERYGMATYCZNEJ}

Analizując najczęściej pojawiające się rysy obrazu tzw. człowieka współczesnego, które są źródłem lub owocem współczesnych kryzysów cywilizacyjnych, F. Blachnicki wskazał, iż człowiek będący produktem współczesnej cywilizacji jest - po pierwsze - człowiekiem zdezintegrowanym. Jest to przede wszystkim dezintegracja między sferą poznawczą a wolą. Następnie jest człowiekiem konsumpcyjnym. Pojęcie życia zamienia się na u-życie. Ponadto jest człowiekiem wyczynowym. Nie liczy się zarówno w świadomości człowieka, jak i w ocenie społecznej jego wartość jako człowieka, jako osoby, tylko jego wyczyn, jego osiągnięcie

\footnotetext{
${ }^{15}$ Tamże, 36-7.

${ }^{16}$ Tamże, 97.
} 
przynoszące sławę, podziw, poklask lub inne doraźne korzyści, np. materialne. Ostatni rys, jaki wymienia Blachnicki, to typ człowiek stada, czyli człowiek zmanipulowany. Człowiek taki jest niewolnikiem, manipulowanym przez innych, zależnym od różnych ośrodków dyspozycyjnych czy społecznych mechanizmów.

Według Blachnickiego pedagogia nowego człowieka, wypracowana w Ruchu Światło-Życie w określeniu celu wychowawczego, stanowi dokładną odpowiedź na braki i zagrożenia współczesnego człowieka. Formacja realizowana w RŚŻ powinna więc sprawić, aby człowiek był zintegrowany. Formuła „Fos-Zoe”, Światło-Życie mieści w sobie postulat wewnętrznej integracji jako centralne zadanie wychowawcze. Poprzez element światła, mającego wcielać się w życie, należy rozumieć światło rozumu, światło sumienia, światło słowa Bożego, światło Chrystusa jako wzoru osobowego, który należy naśladować, i światło Kościoła. Dążenie do jedności światła i życia na pięciu powyższych płaszczyznach zawiera w sobie integralny i wszechstronny program wychowania nowego człowieka. Formuła stanowiąca antytezę modelu człowieka konsumpcyjnego - to człowiek posiadający siebie w dawaniu siebie. Z kolei antytezą człowieka wyczynowego jest człowiek realizujący siebie przez służbę. Blachnicki, parafrazując Kartezjusza, nie mówił „myślę, więc jestem”, ale „służę, więc jestem”. Powyższe aspekty ideału wychowawczego pedagogii nowego człowieka streszczają się w określeniu: człowiek wyzwolony, człowiek prawdziwie wolny. Jest to znów antyteza człowieka stada, który będąc przedmiotem manipulacji, jest uprzedmiotowiony i zniewolony.

Pedagogia, po sformułowaniu celu czy ideału wychowawczego, musi określić środki prowadzące do jego urzeczywistnienia. Blachnicki wskazał trzy główne elementy metody wychowawczej pedagogii nowego człowieka. Pierwszy to Światło-Życie, jako istotny element nie tylko ideału wychowawczego, lecz także swoisty postulat metodyczny. Drugi to oaza wychowawcza jako metoda rekolekcji przeżyciowo-wychowawczych, polegająca na próbie intensywnego zastosowania wszystkich zasad owocnej pedagogii. Dokonuje się je w specjalnie stworzonym środowisku życia, według określonego systemu wartości składających się na pojęcie nowego człowieka, nowej wspólnoty i nowej kultury. Trzecim elementem metody wychowawczej jest wywodząca się z oazy rekolekcyjnej mała grupa, gromadząca się w regularnych odstępach czasu w celu wspólnego pielęgnowania i rozwijania wyniesionych z oazy wartości. Ta mała wspólnota umożliwia wzrost nowego człowieka również w warunkach codziennego życia ${ }^{17}$.

\footnotetext{
${ }^{17}$ Zob. referat przygotowany przez Blachnickiego w 1983 r. na VIII Krajową Kongregację Odpowiedzialnych RŚŻ pt. „Ruch Światło Życie jako pedagogia nowego człowieka”, w Franciszek BLACHNICKI, Charyzmat ,'Światło Życie”. Teksty podstawowe (Krościenko: Światło-Życie, 1987), 27-39.
} 
Trzeba stwierdzić, iż pedagogia nowego człowieka Ruchu Światło-Życie jest w pełni rozbudowanym systemem formacji katechumenalnej, osadzonym w strukturze zwyczajnego życia parafialnego. Jawi się nie tylko jako rzeczywistość organiczna i zwarta, lecz także głęboko eklezjalna. Jak mało który ruch, jest oparta na wszystkich istotnych cechach ruchu eklezjalnego. Zostało to wykazane w wielu naukowych publikacjach ${ }^{18}$. Podmiotem receptywnym tej formacji są z reguły ludzie już ochrzczeni, którzy przeżywali już w swoim życiu jakiś szczątkowy katechumenat, zwłaszcza w związku z tzw. przygotowaniem do Pierwszej Komunii Świętej i w ramach szkolnej katechezy, dlatego zostało przyjęte określenie: deuterokatechumenat, powtórzony katechumenat. Ów system formacji w Ruchu Światło-Życie - zgodnie ze schematem katechumenatu - dzieli się na trzy okresy: okres ewangelizacji, okres właściwego katechumenatu, okres tzw. mystagogii ${ }^{19}$. Na dalszym etapie swego życia ks. Blachnicki opracował - na szeroką skalę zakrojony - jedyny, jak do tej pory, program ewangelizacyjny dla parafii całej Polski - „Plan Wielkiej Ewangelizacji Ad Christum Redemptorem" ${ }^{\prime 20}$. Niestety stan wojenny ogłoszony w Polsce zniweczył to wielkie przedsięwzięcie. Z charyzmatu wychowania nowego człowieka zrodziła się także Krucjata Wyzwolenia Człowieka i ostatnie jego wielkie dzieło - Chrześcijańska Służba Wyzwolenia Narodów ${ }^{21}$.

Można w tym kontekście zapytać: w jakim stopniu RŚŻ - który obecnie rozprzestrzenia się już na inne kontynenty - jest rzeczywistością w naszych parafiach, a w jakim tylko piękną teorią przez niewielu, nawet w ruchu, zrozumianą? Następne pytanie dotyczy recepcji tego charyzmatu przez odpowiedzialnych za przyszłość Kościoła w Polsce. Czy ruch jest widziany i przyjmowany jako szczególny dar dla tego Kościoła? Czy dostrzega się jego wartość i zawartą w nim szansę? Sam Blachnicki zadał pytanie: Czy odczytamy obecną sytuację w naszej Ojczyźnie jako

${ }^{18}$ Zob. np. Bogdan Biela, Kościót-wspólnota. Wspólnota jako zasada urzeczywistniania się Kościoła w ujęciu ks. Franciszka Blachnickiego (1921-1987) (Katowice: Wyd. Kuria Metropolitarna, 1993); Marek SĘDEK, Drogi dojrzatości. Formacja w wybranych ruchach katolickich w Polsce: Ruch Światto-Życie, Ruch Rodzin Nazaretańskich, Droga neokatechumenalna, ruch charyzmatyczny (Krościenko: Wydawnictwo Światło-Życie, 2002); Wojsław CzUPRYŃSKI, Odnowa parafii i duszpasterstwa. Deuterokatechumenalna koncepcja chrześcijańskiej formacji w myśli i dziele ks. Franciszka Blachnickiego (Olsztyn: Wyd. SOL, 2011).

${ }^{19}$ Por. Obrzędy chrześcijańskiego wtajemniczenia dorostych, nr 9-40.

${ }^{20}$ Ewangelizacja wedtug planu „Ad Christum Redemptorem” (Krościenko: Wyd. Światło-Życie, 1988); zob. Biela, Kościót-wspólnota, 123-39.

${ }^{21}$ Szerzej na ten temat zob. Jan Mikulski, Polska teologia wyzwolenia. Teologia wyzwolenia człowieka w ujęciu ks. Franciszka Blachnickiego (Tarnów: Wyd. Biblos, 2000); Henryk BolczyK, Wolny czlowiek - wolny naród. Ostatnie dzieło życia ks. Franciszka Blachnickiego: Chrześcijańska Stużba Wyzwolenia Narodów (Kraków: Wyd. Światło-Życie, 2012). 
naglące wezwanie do podjęcia tego wielkiego daru - charyzmatu wychowania nowego człowieka? 22

\section{INSPIRATOR ODNOWY PARAFII}

Ks. F. Blachnicki był przekonany, że „odnowa soborowa w Polsce tak długo będzie fikcją, jak długo nie zejdzie na płaszczyznę parafii, jak długo nie wypracujemy modelu posoborowego duszpasterstwa parafialnego"23. Dlatego już pod koniec lat siedemdziesiątych minionego stulecia, na skutek doświadczeń związanych z realizowaniem w Ruchu Światło-Życie formacji deuterokatechumenalnej, zaczął skłaniać się ku „katechumenackiej” koncepcji duszpasterstwa, postulując, by z instytucji katechumenatu odczytać i przejąć podstawowe prawa życia i rozwoju wspólnoty chrześcijan. Uzasadniał to następująco: „Skoro celem duszpasterstwa jest budowanie wspólnoty lokalnej, a celem katechumenatu wychowanie i prowadzenie do życia w tej wspólnocie, to można by w sposób zasadny mówić o takiej właśnie koncepcji duszpasterstwa"24. W związku z powyższym jedną z sugestii ks. Blachnickiego była propozycja przejścia od duszpasterstwa do ewangelizacji:

Nie dokonaliśmy bowiem jeszcze ciągle podstawowego przejścia od duszpasterstwa do ewangelizacji. A tymczasem jest to zwrot kopernikański, który musimy dokonać w naszej świadomości [...]. W tej chwili w gruncie rzeczy koncepcja soborowa - zwłaszcza ta, która znalazła swój wyraz w adhortacji Evangelii nuntiandi - i ta koncepcja, która jeszcze trwa siłą ciężkości, to są koncepcje wobec siebie ustawione konfliktowo. My sobie nawet tego konfliktu nie uświadamiamy. Sytuacja, generalnie rzecz biorąc, jest taka, że próbujemy „czapką soborową” przykryć to wszystko, co było i co jest, ale niczego nie zmieniamy. Pod inną ,pokrywką” mieści się to samo, co dawniej. To jest specyfika obecnej sytuacji. Chociażby nawet w samej dziedzinie terminologii. Termin „ewangelizacja” znalazł prawo obywatelstwa i ciągle się o tym mówi [...]. Ale gdy się jednak przypatrzymy temu, co się kryje pod tymi hasłami, to zobaczymy, że dokładnie to samo, co dawniej nazywano duszpasterstwem [...]. Cytuje się adhortacje, dokumenty soborowe, ale to wszystko jest na płaszczyźnie intelektualnej, wśród intelektualistów w różnych komisjach, na zjazdach, w referatach, w czasopismach [...]. Koncepcja duszpasterstwa i koncepcja ewangelizacji różnią się zasadniczo tym, że jedna jest statyczna, a druga dynamiczna ${ }^{25}$.

${ }^{22}$ BlachNICKI, Ruch Światto Życie jako pedagogia nowego człowieka, 39.

${ }^{23}$ Franciszek Blachnicki, Diakonii Ruchu Oaza Rekolekcyjna Światto-Życie (Krościenko: Światło-Życie, 1987), 146.

${ }^{24}$ Franciszek BlachNicki, Formacja stużby liturgicznej jako jedna z form młodzieżowego deuterokatechumenatu w parafii, Biblioteka Animatora, z. 2 (Krościenko n. Dunajcem, 1977), 59-60.

${ }^{25}$ Franciszek Blachnicki, Rekolekcje dla Wspólnoty Kapłanów Chrystusa Stugi (Lublin: Wyd. Światło-Życie, 1991), 11-2. 
Z chwilą II Soboru Watykańskiego - przekonywał Blachnicki - weszliśmy już w fazę terapii. Przyniósł on nowy obraz Kościoła i życia chrześcijańskiego, jako lekarstwo na niedomagania i braki modelu tradycyjnego. Dlatego też konsekwentnie dążył do tego, aby parafia - to ostateczne umiejscowienie Kościoła (por. ChL 26) - stawała się wspólnotą wspólnot. Warunkiem jednak ,wszelkiego postępu, odnowy, reformy jest krytyczne uświadomienie sobie i zanalizowanie aktualnych błędów i braków”26. Dlatego też najistotniejsze zagrożenie tkwi w odnowie pozornej, czysto zewnętrznej, legalistycznej. Doświadczenie ogólne jest jednoznaczne: tradycyjny model życia chrześcijańskiego i duszpasterstwa nie wytrzymuje próby współczesnych przemian. Duszpasterstwo ograniczające się do głoszenia słowa Bożego, szafarstwa sakramentów oraz stwarzania kultycznych ram służby Bożej nie może być dziś wystarczające. Duszpasterstwo nie wspierane pracą i oddziaływaniem środowiska wychowującego zawisło jakby w próżni i nie jest zdolne samo osiągnąć celu, jakim jest wychowanie nowego człowieka. Papież Franciszek w Evangelii gaudium mówi - „uczniów-misjonarzy”. Tego celu nie zrealizuje model tradycyjny (trydencki) parafii, który przez swą centralizację staje się modelem statycznym, bez misyjnej dynamiki.

Model tradycyjny parafii, wywodzący się z reformy Soboru Trydenckiego, to wydzielone terytorium, z pewną grupą ludzi pod przewodnictwem odpowiedniego pasterza. Oznacza to podział parafii na principium aktywne i bierne, na Kościół nauczający i słuchający. Zachodzi dwustronna relacja: ,ja-oni”. Nie ma świadomości „my”, a dopiero wtedy, gdy pojawia się taka świadomość, można mówić, że Kościół jest wspólnotą i to zarówno w wymiarze wertykalnym, jak i horyzontalnym. Wertykalnym, bo duszpasterz i wierni są razem odpowiedzialni za budowanie Kościoła, i horyzontalnym, w wielorakich kontaktach między wiernymi, które aktualizują się w konkretnych wspólnotach. W potrydenckim modelu parafii, obejmującym pewien krąg ludzi, istnieje i stale wzrasta kategoria ludzi niepraktykujących bądź deklarujących się wprost jako niewierzący. Obok nich istnieje drugi krąg - praktykujących. Jednakże ci praktykujący nie mają większego wpływu na niepraktykujących, gdyż nie istnieje w ich świadomości eklezjalne „my”. Ogólnie więc zaznacza się tendencja ilościowego wzrastania kręgu ludzi niepraktykujących i coraz mniejszego wpływu pasterza. Cały ten model parafii jest więc modelem statycznym, nie ma w nim dynamiki misyjnej. Istnieje stały punkt, do którego ludzie przychodzą, żeby zaspokoić swoje potrzeby religijne, a sfera wpływu duszpasterzy zamyka się faktycznie w kręgu tych ludzi, którzy przychodzą do kościoła, salki katechetycznej czy kancelarii parafialneje27.

\footnotetext{
${ }^{26}$ Franciszek Blachnicki, Katechetyka fundamentalna (Lublin: Wyd. KUL, 1979), 120.

${ }^{27}$ Franciszek Blachnicki, Parafia wspólnota - wspólnoty w parafii, Biblioteka Animatora, z. 1 (Krościenko n. Dunajcem, 1977), 96-100.
} 
Z kolei model parafii wspólnotowej ma kilka kręgów. Według tego modelu do pierwszego kręgu, tego najbardziej zewnętrznego, należy grupa zarówno ochrzczonych, jak i nieochrzczonych. Jest to krąg misyjny, który stanowi zadanie dla pozostałych, obejmujących go swoją modlitwą, troską i dynamiką ewangelizacyjną. Drugi krąg stanowią wierni praktykujący, którzy są w Kościele na zasadzie relacji ,ja-oni”, traktujący parafię jako punkt świadczący usługi religijne. Ten krąg musi być także terenem pracy formacyjnej i wychowawczej; tak, by ci wierni mogli być świadkami Chrystusa dla innych. Kolejny krąg tworzą już małe grupy. Należą do niego ludzie z dwóch poprzednich kręgów tworzący grupy katechumenalne. Tutaj odbywa się systematyczna formacja uzupełniająca braki tradycyjnej formacji religijnej oraz wdrażanie do życia we wspólnocie chrześcijańskiej. W tych grupach dokonuje się proces dojrzewania eklezjalnej świadomości „my”. Te wspólnoty stają się „żywymi komórkami”, które oddziałują na całość parafii. Z tych grup tworzą się z kolei kręgi wspólnot diakonijnych. Jedne z nich są odpowiedzialne za jakieś środowisko, np. blok mieszkalny, dzielnicę. Inne przejmują odpowiedzialność za pewne funkcje żywotne Kościoła, które muszą być realizowane w każdej wspólnocie lokalnej. Będzie to na przykład diakonia do spraw ewangelizacji, liturgii, środków przekazu, spraw charytatywnych. Ze względu na wielką liczbę grup we wspólnotowej parafii, musi istnieć sztab diakoni - rada apostolska czy też faktycznie działająca rada parafialna, która współdziała i koordynuje działalność różnych grup. Ostatnim kręgiem - będącym w samym centrum parafii - jest diakonia stała, w skład której wchodzi proboszcz, wikariusze parafialni, a także grupa świeckich całkowicie oddanych wspólnocie lokalnej. Grupa ta powinna być znakiem dla całej wspólnoty parafialnej tego, do czego parafia ma być wychowywana i jak się ma rozwijać. Dlatego też niezwykle istotne jest świadectwo tej grupy.

Zarysowany model budowania parafii spełnia wymagania pastoralnego nawrócenia, do którego wzywa papież Franciszek w adhortacji Evangelii gaudium (por. 25-33). Jest to bowiem model wspólnotowy, a jednocześnie model misyjny, którego dynamika i inspiracja nie zatrzymuje się na jakimś kręgu. Z jednej strony - od środka do peryferii - działa dynamika ewangelizacji, z drugiej zaś strony - od peryferii do środka - występuje dynamika wzrostu. W ten sposób tworzy się „,nowa parafia” - misyjna wspólnota wspólnot ${ }^{28}$. Ważną rolę w tym modelu spełniają wierni świeccy

\footnotetext{
${ }^{28}$ Jan CHRAPEK, „Od potrydenckiego do powatykańskiego modelu parafii”, Collectanea Theologica 49 f. 1 (1979): 141-50. Pojawiający się jeszcze czasami dylemat, czy Kościół powinien koncentrować się na tworzeniu prawdziwych wspólnot eklezjalnych, akceptując tym samym sytuację diaspory, czy też raczej troska Kościoła powinna pójść w kierunku objęcia jak najszerszych mas, w tym kontekście traci rację bytu. Soborowa perspektywa jest jednoznaczna. Wynika ona przede wszystkim z istoty Kościoła, który z natury swej jest misyjny. Poza tym Kościół będzie tym bardziej skutecz-
} 
oraz tzw. kościelne wspólnoty podstawowe. Zwrócił na to szczególną uwagę Jan Paweł II, który w adhortacji Christifideles laici podał dwa podstawowe warunki, aby parafie mogły stanowić prawdziwe wspólnoty. Po pierwsze, władze lokalne powinny zadbać „o przystosowanie struktur parafialnych z dużą elastycznością, jaką w tej dziedzinie dopuszcza Kodeks Prawa Kanonicznego, mając na względzie przede wszystkim udział świeckich w odpowiedzialności duszpasterskiej” (ChL 26). Po drugie, chodzi „o tworzenie niewielkich podstawowych wspólnot kościelnych, zwanych także wspólnotami żywymi, w których wierni mogą przekazywać sobie nawzajem Słowo Boże oraz służyć innym i praktykować miłość. Wspólnoty te są prawdziwym wyrazem kościelnej komunii i ośrodkami ewangelizacji, działającymi w łączności ze swoimi pasterzami" (tamże). Podobne tezy pojawiają się w encyklice Redemptoris missio, która potwierdza ich znaczenie oraz wskazuje na to, że wspólnoty podstawowe są ,znakiem żywotności Kościoła, narzędziem formacji i ewangelizacji, ważnym punktem wyjścia dla nowego społeczeństwa zbudowanego na fundamencie cywilizacji miłości” (nr 51). Również II Polski Synod Plenarny w dokumencie „Potrzeba i zadania nowej ewangelizacji na przełomie II i III Tysiąclecia Chrześcijaństwa”, mówiąc, iż „należy usilnie starać się o kształtowanie modelu parafii jako wspólnoty wspólnot” ( $\mathrm{nr} 43$ ), podkreślił, że w „kształtowaniu tego modelu wielką rolę mogą odgrywać kościelne wspólnoty podstawowe, czyli wspólnoty sąsiedzkie" (nr 44).

Aby parafia stawała się wspólnotą misyjną i „szkołą komunii” (por. NMI 43), warunkiem nieodzownym jest świadomość posiadania przez duszpasterzy integralnej i organicznej wizji budowania wspólnoty lokalnej. Pasterz parafii ogarnia wtedy całość procesu rozwojowego, który ma prowadzić do urzeczywistnienia wspólnoty Kościoła. Proces ten rozpoczyna się od ewangelizacji, która inicjuje procesy wyzwoleńcze w ludziach i danym środowisku. Kolejnym etapem jest wdrażanie poprzez formację katechumenalną do życia w eklezjalnej wspólnocie. Ostatecznie chodzi o to, aby całe duszpasterstwo było tak przebudowane, by służyło formowaniu podstawowych wspólnot życia chrześcijańskiego w parafii. Są one pośrednimi etapami w budowaniu parafialnej więzi wspólnotowej. W nich jest możliwe istnienie komunikacji międzyosobowej, służącej w efekcie budowaniu parafii jako misyjnej

nym sakramentem zbawienia dla wszystkich, im bardziej będzie sobą, starając się we wspólnocie lokalnej objawić w pełni swoją istotę. Z tego względu należy przyjąć zasadę prymatu intensywnego i jakościowego urzeczywistniania się Kościoła przed „ilościowym”. Im intensywniej Kościół będzie urzeczywistniał swoją istotę, stając się braterską wspólnotą, tym ekstensywniej będzie jako sakrament zbawienia oddziaływał na innych ludzi. Por. Franciszek BlACHNICKI, Teologia pastoralna ogólna, cz. 2 (Lublin: Wyd. KUL, 1971), 431-2. 
wspólnoty wspólnot ${ }^{29}$. Realizując budowanie modelu wspólnotowego, parafie duże pod względem liczebności wiernych powinny być podzielone na mniejsze jednostki organizacyjne. Istniejące w nich wspólnoty sąsiedzkie mogą stać się najbliższą każdemu katolikowi, najbardziej rodzinną, małą, podstawową wspólnotą kościelną. To w nich i poprzez nie świeccy mogą spełniać swoją podmiotowość w Kościele. Takie wspólnoty ewangelizują swoje środowisko, wychowując do świadomej wiary i współodpowiedzialności. Jawi się w związku z tym pilna potrzeba, aby w każdej parafii istniał strategiczny plan urzeczywistniania modelu parafii wspólnotowej. Pomocą w realizacji takiego modelu parafii na płaszczyźnie programowania i planowania mogą służyć posoborowe ruchy odnowy Kościoła realizujące wypracowane przez siebie projekty odnowy parafii, a więc mające konkretny sposób budowania parafii wspólnoty wspólnot, np. projekt „Nowy Obraz Parafii” Ruchu dla Lepszego Świata czy też metoda „ewangelizacyjnych komórek parafialnych”. Niezwykle inspirująca jest także realizowana w kościołach protestanckich tzw. strategia małych grup ${ }^{30}$. Okazuje się, że te małe grupy są idealnym miejscem do formowania uczniów-misjonarzy, do czego tak usilnie zachęca papież Franciszek w adhortacji Evangelii gaudium.

Na gruncie osiągnięć teologii kerygmatycznej oraz komunijnej wizji Kościoła możliwa jest całościowa (katechumenalna) koncepcja budowania Kościoła we wspólnocie lokalnej ${ }^{31}$. Proces urzeczywistniania się Kościoła rozpoczyna się od

\footnotetext{
${ }^{29}$ Franciszek BLACHNicKI, „Etapy realizacji wspólnotowego modelu parafii. Wizja Ruchu Światło-Życie”, Koinonia nr 2(1979): 12-20; Franciszek BLACHNICKI, „Formacja służby liturgicznej jako jedna z form młodzieżowego deuterokatechumenatu w parafii”, Collectanea Theologica 46, f. 4(1976): 51.

${ }^{30}$ Strategia ta koncentruje się na realizacji pięciu biblijnych celów: byciu uczniem Chrystusa, budowaniu relacji braterskich, służbie, ewangelizacji i uwielbieniu. Przykładem zastosowania takiej strategii jest założony w 1980 r. przez pastora Ricka Warrena ewangelikalny Saddleback Church, znajdujący się w Lake Forest w Kalifornii. Frekwencja w tygodniu wynosi ok. 22000 uczestników. „Strategia małych grup” polega na tym, aby w parafii nie tyle istniały małe grupy, lecz aby wspólnota parafialna funkcjonowała w oparciu o małe grupy. Zob. Rick WARREN, Kościót świadomy celu. Rozwój w oparciu o bezkompromisowe przestanie i misję (Ustroń: Wyd. Koinonia, 2005); Steven GLAdEN, Małe grupy świadome celu. Jak tworzyć zdrowe wspólnoty? (Gubin: Wyd. Przystanek Jezus, 2016); Bogdan Biela i Ireneusz Celary, Wstuchani w Ducha. Ku odnowie wspólnoty parafialnej - rodziny Bożej (Katowice: Wyd. WT UŚ, Księgarnia św. Jacka, 2019), 71-85; https://saddleback.com/. [dostęp: 25.11.2019].

${ }^{31}$ Zob. Bogdan Biela, Parafia miejscem urzeczywistniania się komunii Kościoła (Katowice: Wyd. WT UŚ, Księgarnia św. Jacka, 2006).
} 
ewangelizacji, która inicjuje procesy wyzwoleńcze w ludziach i danym środowisku. Kolejnym etapem jest wdrażanie, poprzez formację (deutero-)katechumenalną, do życia w eklezjalnej wspólnocie. Życie tej wspólnoty koncentruje się wokół liturgii, która objawia i tworzy Kościół. Trzeci etap budowania parafialnej wspólnoty związany jest z diakonią, gdyż do wspólnoty można się włączyć przez aktualizację swoich charyzmatów. Dlatego też parafia - jako wspólnota służb i charyzmatów powinna wszystkim swoim członkom umożliwić służenie posiadanym darem niezbędnym dla właściwego i całościowego wzrostu Kościoła ${ }^{32}$.

Pięćdziesiąt lat po Soborze Watykańskim II ciągle parafia (przynajmniej w Polsce) spełnia niezastąpioną rolę w dziele tworzenia środowisk żywej i misyjnej komunii (por. ChL 28), gdyż to ona ciągle stanowi podstawową osnowę organizacyjną duszpasterstwa. Trzeba jednak powiedzieć, że współczesna parafia w zasadzie nie nadąża za potrzebami zmian. Między innymi na skutek wielu funkcjonujących mechanizmów kościelnych jest mało elastyczna i z trudnością adaptuje się we współczesnym, pluralistycznym i zsekularyzowanym środowisku. Nowość Soboru Watykańskiego II dotknęła w praktyce bardziej zewnętrznej sfery parafii niż jej istotnych elementów, nie odmieniła jej wnętrza. Dlatego kondycję współczesnych parafii można nazwać sytuacją „przejścia”, jest ona swego rodzaju „hybrydą”, połączeniem mało spójnych elementów parafii tradycyjnej oraz przejawów współczesnego chrześcijaństwa, jakim są głównie nowe ruchy i wspólnoty. W efekcie ciągle dominuje typ parafii hierarchicznej i organizacyjnej oraz model duszpasterstwa kultycznego i autorytatywnego ${ }^{33}$.

Można stwierdzić, iż na początku XXI stulecia wizja Kościoła i cura pastoralis ks. Blachnickiego jest tak samo aktualna jak wówczas, gdy pisał książki, artykuły i wygłaszał swoje konferencje ${ }^{34}$. Przez całe swoje życie Sługa Boży ujawniał twarz gwałtownika Królestwa Bożego ${ }^{35}$. Zaskakiwał, niepokoił, pobudzał do myślenia,

${ }^{32}$ Franciszek BlachNicki, „Charyzmat «Światło-Życie» w służbie odnowy Kościoła lokalnego”, w BlaChNICKI, Charyzmat „Światło Życie”, 71.

${ }^{33}$ Zob. Bogdan Biela, Pastoralne nawrócenie w teorii i praktyce parafialnej (Katowice: Wyd. Emmanuel, 2014), 61-76; Mieczysław PolaK, Parafia dzisiaj. Podstawy i kierunki duszpasterskiej odnowy (Poznań: WT UAM, 2007), 33-58.

${ }^{34}$ Zob. Franciszek Blachnicki, Bibliografia prac ks. Franciszka Blachnickiego, opr. Grażyna Wilczyńska (Krościenko: Wyd. Instytut im. ks. F. Blachnickiego, 2002).

${ }^{35} \mathrm{~W}$ telegramie kondolencyjnym papieża Jana Pawła II po śmierci ks. F. Blachnickiego, przesłanym 28 lutego 1987 r. na ręce bp. Szczepana Wesołego, czytamy: „Bóg powołał do Siebie Ks. Prof. Franciszka Blachnickiego i śmierć ta napełniła smutkiem wiele ludzkich serc i środowisk. Odszedł gorliwy apostoł nawrócenia i wewnętrznej odnowy człowieka i wielki duszpasterz młodzieży. Z Jego inspiracji zrodził się specyficzny kształt życia oazowego na polskiej ziemi. Swoje liczne talenty umysłu i serca, jakiś szczególny charyzmat, jakim obdarzył Go Bóg, oddał sprawie budowy Królestwa 
nieraz wręcz szokował małodusznych. Można zapytać na koniec: Czy jego wizja pastoralna, którą proponował i realizował w RŚż, jest ciągle realna? Czy niektóre jego sugestie nie budzą lęku? Co by było, gdyby rzeczywiście jego wizja się spełniła? Czy nie wystraszylibyśmy ludzi stojących - i w rzeczywistości, i w przenośni - na progu świątyni albo w kruchcie? Czy nie odeszłyby od Kościoła osoby do niego przywiązane, ale zrażone takim radykalizmem? Podobne pytania można mnożyć. Zaraz przychodzi jednak refleksja: Czemu wątpisz, małej wiary? Przecież tyle razy można się już było przekonać, że tych z peryferii pociąga w Kościele nie minimalizm i obniżanie poprzeczki, lecz stawianie wysokich wymagań ${ }^{36}$. Wystarczy choćby zobaczyć, co się dzieje z Kościołem na zachodzie Europy.

\section{BIBLIOGRAFIA}

Biela, Bogdan. Kościót - wspólnota. Wspólnota jako zasada urzeczywistniania się Kościoła w ujęciu

ks. Franciszka Blachnickiego (1921-1987). Katowice: Wyd. Kuria Metropolitarna, 1993.

Biela, Bogdan. Parafia miejscem urzeczywistniania się komunii Kościoła. Katowice: Wyd. WT UŚ, Księgarnia św. Jacka, 2006.

BIELA, Bogdan. Pastoralne nawrócenie w teorii i praktyce parafialnej. Katowice: Wyd. Emmanuel, 2014. Biela, Bogdan i Ireneusz Celary. Wstuchani w Ducha. Ku odnowie wspólnoty parafialnej - rodziny Bożej. Katowice: Wyd. WT UŚ, Księgarnia św. Jacka, 2019.

BlachNicKi, Franciszek. „Analiza, diagnoza, terapia”. Tygodnik Powszechny 27, nr 10(1973): 1-2.

BlachNicki, Franciszek. Bibliografia prac ks. Franciszka Blachnickiego, opr. Grażyna Wilczyńska. Krościenko: Wyd. Instytut im. ks. F. Blachnickiego, 2002.

BlaCHNICKI, Franciszek. Charyzmat „Światto-Życie”w stużbie odnowy Kościoła lokalnego. W Franciszek Blachnicki. Charyzmat „Światto Życie. Teksty podstawowe, 66-77. Krościenko: Wyd. Światło-Życie, 1987.

BLACHNICKI, Franciszek. „Etapy realizacji wspólnotowego modelu parafii. Wizja Ruchu ŚwiatłoŻycie". Koinonia nr 2(1979): 12-20.

BlaChNiCKI, Franciszek. Ewangelizacja wedtug planu „Ad Christum Redemptorem”. Krościenko: Wyd. Światło-Życie, 1988.

BLACHNICKI, Franciszek. „Formacja służby liturgicznej jako jedna z form młodzieżowego deuterokatechumenatu w parafii". Collectanea Theologica 46, f. 4(1976): 87-93.

BlaCHNICKI, Franciszek. Katechetyka fundamentalna. Lublin: Wyd. KUL, 1979.

Bożego. Budował je modlitwą, apostolstwem, cierpieniem i budował z taką determinacją, że słusznie myślimy o Nim jako o «gwałtowniku» tego Królestwa (por. Mt 11, 12). Dziękujemy Bogu za wszelkie dobro, jakie stało się udziałem ludzi przez Niego. Modlimy się gorąco o pełnię światła i życia dla Jego duszy. Wieloraka działalność i służba Kościołowi i w Kościele, budzenie i ożywianie zaangażowania świeckich, zmaganie się o trzeźwość Narodu, troska o młodych i rodziny uczyniły ks. Franciszka Blachnickiego niezwykłym świadkiem wiary. Stał się on bowiem głosem, który wzywał wszystkich świeckich, by na co dzień żyli tajemnicą Kościoła”. Zob. oaza.pl. Serwis WWW Ruchu Światło-Życie.

${ }^{36}$ Por. Zbigniew Nosowski, „Przedmowa”, w Blachnicki, Sympatycy czy chrześcijanie, 10-11. 
BLACHNICKI, Franciszek, Oaza Rekolekcyjna Diakonii Ruchu Światto-Życie. Krościenko: Wyd. ŚwiatłoŻycie, 1987.

BlachNicki, Franciszek. Parafia wspólnota-wspólnoty w parafii. Biblioteka Animatora, z. 1. Krościenko n. Dunajcem, 1977.

BlachNicki, Franciszek. Rekolekcje dla Wspólnoty Kapłanów Chrystusa Stugi. Lublin: Wyd. ŚwiatłoŻycie, 1991.

BLACHNICKI, Franciszek. „Ruch Światło Życie jako pedagogia nowego człowieka”. W Franciszek Blachnicki. Charyzmat „Światło Życie”. Teksty podstawowe, 27-39. Krościenko: ŚwiatłoŻycie, 1987.

BlaCHNICKI, Franciszek. Sympatycy czy chrześcijanie? Katechumenat na dzisiejsza godzinę, red. Dorota Franków. Krościenko: Wyd. Światło-Życie, 2002.

BLAChNicki, Franciszek. Teologia pastoralna ogólna, cz. 2. Lublin: Wyd. KUL, 1971.

BoLCZYK, Henryk. Wolny człowiek - wolny naród. Ostatnie dzieło życia ks. Franciszka Blachnickiego: Chrześcijańska Stużba Wyzwolenia Narodów. Kraków: Wyd. Światło-Życie, 2012.

CHRAPEK, Jan. Od potrydenckiego do powatykańskiego modelu parafii. „Collectanea Theologica” 49, f. 1(1979): 141-50.

CZUPRYŃSKI, Wojsław. Odnowa parafii i duszpasterstwa. Deuterokatechumenalna koncepcja chrześcijańskiej formacji w myśli i dziele ks. Franciszka Blachnickiego. Olsztyn: Wyd. SOL, 2011.

FranciszeK. Evangelii gaudium. Adhortacja apostolska o głoszeniu Ewangelii w dzisiejszym świecie (24.11.2013). Kraków: Wyd. M, 2013.

FrANCISZEK. Veritatis gaudium. Konstytucja apostolska o uniwersytetach $i$ wydziałach kościelnych (08.12.2017). Tarnów: Biblos, 2018.

Gladen, Steven. Małe grupy świadome celu. Jak tworzyć zdrowe wspólnoty? Gubin: Wyd. Przystanek Jezus, 2016.

JAKLEWICZ, Tomasz. „Kerygmat”. W Leksykon Teologii Pastoralnej, red. Ryszard Kamiński, Wiesław Przygoda i Marek Fiałkowski, 371-4. Lublin: TN KUL, 2006.

JAN PAwEe II. Christifideles laici. Adhortacja apostolska o powołaniu i misji świeckich w Kościele i w świecie dwadzieścia lat po Soborze watykańskim II (30.12.1988). Wrocław: Wyd. TUM, 1995.

JAN PAWEe II. Redemptoris missio. Encyklika o stałej aktualności postania misyjnego (07.12.1990). Wyd. TUM, 1995.

Kongregacja Kultu Bożego. Ordo initiationis christianae adultorum (6 I 1972). Obrzędy chrześcijańskiego wtajemniczenia dorostych. Katowice: Księgarnia św. Jacka, 1988.

MikUlski, Jan. Polska teologia wyzwolenia. Teologia wyzwolenia człowieka w ujęciu ks. Franciszka Blachnickiego. Tarnów: Wyd. Biblos, 2000.

Nosowski, Zbigniew. „Przedmowa”. W Franciszek Blachnicki. Sympatycy czy chrześcijanie? Katechumenat na dzisiejsza godzinę, red. Dorota Franków, 6-12. Krościenko: Wyd. ŚwiatłoŻycie, 2002.

PolaK, Mieczysław. Parafia dzisiaj. Podstawy i kierunki duszpasterskiej odnowy. Poznań: WT UAM, 2007.

Potrzeby i zadania nowej ewangelizacji na przełomie II i III Tysiaclecia Chrześcijaństwa. W II Polski Synod Plenarny (1991-1999), 10-28. Poznań, Warszawa: Wyd. Pallottinum, 2001.

SĘDEK, Marek. Drogi dojrzałości. Formacja w wybranych ruchach katolickich w Polsce: Ruch ŚwiatłoŻycie, Ruch Rodzin Nazaretańskich, Droga neokatechumenalna, ruch charyzmatyczny. Krościenko: Wyd. Światło-Życie, 2002.

WARREN, Rick. Kościót świadomy celu. Rozwój w oparciu o bezkompromisowe przesłanie i misję. Ustroń: Wyd. Koinonia, 2005.

Więksi i mniejsi prorocy Europy Środkowo-Wschodniej XX wieku, red. Karol Karol, Stanisław Celestyn Napiórkowski i Kazimierz Pek. Lublin: Wyd. KUL, 2003.

WodarczyK, Adam. Prorok żywego Kościoła. Ks. Franciszek Blachnicki (1921-1987) - życie i dziatalność. Katowice: Wyd. Emmanuel, 2008. 


\section{KSIĄDZ FRANCISZEK BLACHNICKI \\ - PREKURSOR TEOLOGII KERYGMATYCZNEJ W POLSCE}

\section{Streszczenie}

Papież Franciszek stwierdził, iż „teologia po Veritatis gaudium jest teologią kerygmatyczną, teologią rozeznania, miłosierdzia i akceptacji, która nawiązuje dialog ze społeczeństwem, kulturami i religiami w celu budowania pokojowego współistnienia ludzi i narodów" (21.06.2019). Warto w tym kontekście zwrócić uwagę na prekursora teologii kerygmatycznej w Polsce, ks. Franciszka Blachnickiego (1921-1987), który był nie tylko teoretykiem, ale i praktykiem teologii kerygmatycznej. Jako teoretyk wypracował podwaliny pod katechezę fundamentalną, w której wskazał, że dzisiejsze formy katechumenatu nie odpowiadają wymaganiom czasów współczesnych. Blachnicki miał świadomość, że centralnym problemem pastoralnym jest utrata przez Kościół środowiska żywej wiary i miłości, które mogłoby przyjmować w siebie nowe pokolenie chrześcijan. Istniejący system katechizacji dzieci i młodzieży pojętej na sposób szkolny, intelektualistyczny, jako nauczanie religii, nie potrafi w tej sytuacji spełnić zadań katechumenatu, ponieważ nie jest systemem wychowawczym, który wdraża do życia chrześcijańskiego we wspólnocie Kościoła. W związku z powyższym Blachnicki był przekonany, że trzeba wprowadzić uzupełniający katechumenat dla osób już ochrzczonych - zarówno dorosłych, jak dzieci i młodzieży - wykorzystując wskazówki posoborowego nauczania Kościoła, zwłaszcza zawarte w dokumencie o inicjacji chrześcijańskiej dorosłych. W efekcie ks. Blachnicki w latach sześćdziesiątych ubiegłego wieku na bazie rekolekcji oazowych stworzył Ruch Żywego Kościoła, nazwany później Ruchem Światło-Życie. W ramach formacji deuterokatechumenalnej pokazał konkretną drogę realizacji postulatów wynikających bezpośrednio ze zdobyczy teologii kerygmatycznej oraz ukazał „katechumenacką” koncepcję duszpasterstwa mogącą odnowić współczesną parafię wspólnotę wspólnot.

Słowa kluczowe: teologia kerygmatyczna; katechumenat; Ruch Światło-Życie; parafia. 